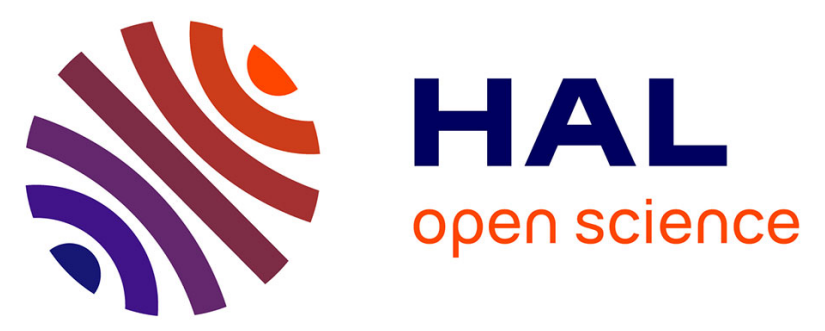

\title{
Catalytic dense membranes of doped Bi4V2O11 (BIMEVOX) for selective partial oxidation: chemistry of defects versus catalysis
}

Axel Löfberg, Hervé Bodet, Caroline Pirovano, Marlu César Steil, Rose-Noëlle Vannier, Elisabeth Bordes-Richard

\section{To cite this version:}

Axel Löfberg, Hervé Bodet, Caroline Pirovano, Marlu César Steil, Rose-Noëlle Vannier, et al.. Catalytic dense membranes of doped Bi4V2O11 (BIMEVOX) for selective partial oxidation: chemistry of defects versus catalysis. Topics in Catalysis, 2006, 38, pp.169-179. 10.1007/s11244-006-0082-x . hal-00104262

\section{HAL Id: hal-00104262 \\ https://hal.science/hal-00104262}

Submitted on 6 Oct 2006

HAL is a multi-disciplinary open access archive for the deposit and dissemination of scientific research documents, whether they are published or not. The documents may come from teaching and research institutions in France or abroad, or from public or private research centers.
L'archive ouverte pluridisciplinaire HAL, est destinée au dépôt et à la diffusion de documents scientifiques de niveau recherche, publiés ou non, émanant des établissements d'enseignement et de recherche français ou étrangers, des laboratoires publics ou privés. 
Catalytic dense membranes of doped $\mathrm{Bi}_{4} \mathrm{~V}_{2} \mathrm{O}_{11}$ (BIMEVOX) for selective partial oxidation: chemistry of defects $v s$. catalysis

Axel Löfberg, Hervé Bodet, Caroline Pirovano, Marlu César Steil, Rose-Noëlle Vannier and Elisabeth Bordes-Richard*

Unité de Catalyse et de Chimie du Solide, UMR CNRS 8181,ENSCL-ECL-USTL, 59655 Villeneuve d'Ascq Cedex, France

E-mail: Elisabeth.Bordes@ensc-lille.fr 


\begin{abstract}
A catalytic dense membrane reactor (CDMR) is used to physically separate the reaction step from the reoxidation of the catalyst. By decoupling the redox mechanism prevailing in mild oxidation of hydrocarbons, the operating conditions may be optimized resulting in an increase of selectivity. The membranes are made up of BIMEVOX oxides, obtained by partial substitution of $\mathrm{V}$ in $\gamma-\mathrm{Bi}_{4} \mathrm{~V}_{2} \mathrm{O}_{11}$ by $\mathrm{ME}(\mathrm{Co}, \mathrm{Cu}, \mathrm{Ta})$. Experiments performed on BIMEVOX dense membranes using propene and propane are described in terms of, (i) active sites on polished or unpolished surfaces, (ii) operating conditions ( $\mathrm{T}, \mathrm{pO}_{2}$ in the high oxygen partial pressure compartment), which determine the selectivity, either to mild oxidation products (acrolein, hexadiene, $\mathrm{CO}$ ), or to partial oxidation products $\left(\mathrm{CO}, \mathrm{H}_{2}\right)$, and, (iii) nature of $\mathrm{ME}$ cations and relative properties. The discussion deals with the respective role of electronic vs. oxide ion conductivities which depend on defects in the structure as well as on the redox properties of cations.
\end{abstract}

KEY WORDS: catalytic dense membrane reactor; syngas; mild oxidation of propene; partial oxidation of propane; oxide ion conductivity; electronic conductivity. 


\section{Introduction}

The mild oxidation of hydrocarbons proceeds by means of the Mars and van Krevelen mechanism [1], according to which the oxygen responsible for the selective oxidation of the reactant comes directly from the lattice of the oxidic catalyst. As these reactions are structuresensitive, most progresses recently made in the understanding of this particular case of catalysis are due to the fact that researchers have considered concepts stemming from both solid state chemistry and catalysis fields. In his theory on the role of semi-conductivity in catalysis [2], Wolkenstein searched for a concept from solid state physics likely to bring informations about the way electrons could be exchanged between an oxide and the reactants. Well considered for a while, this theory has later been quite rejected because of its lack of generalisation. More success was met when considering the way crystal structures could bring informations. Stone [3] introduced the concept of coordinatively unsaturated surface atoms, and used deliberately solid solutions prepared by dissolving a transition metal oxide in an insulating diamagnetic oxide, to determine the role of the metal in a same structural matrix. Grasselli's group published papers on the crystal structure of $\mathrm{USbO}_{\mathrm{x}}$ oxides as well as on their catalytic properties in the ammoxidation of propene to acrylonitrile [4,5]. Another group of workers headed by J. Haber soon recognized the relative role of nucleophilic surface lattice oxygen $\mathrm{O}^{2-}$ vs. electrophilic adsorbed species in selective oxidation [6]. In the same period, other researchers $[7,8,9]$ also began to consider the bulk structure as a basis to imagine how species could be distributed on the surface. The yields of oxidized bulk chemicals like methanol, acrolein and the like (acrylonitrile, acrylic acid), maleic anhydride, phthalic anhydride, etc., have been strongly increased thanks to a better understanding of the solid state chemistry of molybdates, vanadophosphates and supported vanadium oxide, respectively. 
Metallic oxides are able to provide oxygen during reaction for several reasons (variable oxidation degree and coordination of cations, among others), while there is a ballet of oxygen specie, vacancies and electrons coming back and forth between bulk and surface. The mobility of oxygen species has soon been considered as an important factor, and isotopic exchange of labelled ${ }^{18} \mathrm{O}$ with the surface ${ }^{16} \mathrm{O}$ oxygen is a convenient method which has delivered many informations [10]. The oxide ion conductivity has not received much attention, except in the community interested in fuel cells or ceramic oxygen generators $[11,12]$, probably because this parameter stands for the bulk and not for the surface of oxides. Similarly, the electronic n- or p-type conductivity has been considered as a valid parameter only in few studies, certainly because of the semi-failure of Wolkenstein's theory. However, the power of this approach has recently been shown, for example in accounting for synergistic effects in multicomponent molybdates used in the (amm)oxidation of propene to acrolein or acrylonitrile [13], or in understanding the influence of $\mathrm{Na}_{2} \mathrm{O}$ doping of $\mathrm{CaO}$ on the oxidative coupling of methane to ethane and ethylene [14].

The redox mechanism is responsible for another, very important feature in selective oxidation: the influence of the operating reaction conditions on the solid state properties of the catalyst in the chosen catalytic reactor. The hydrocarbon/oxygen mixture is itself a redox mixture which faces the solid state redox system, and the distribution of oxidized and reduced sites is modified until the steady state is reached. This is the reason why an equilibration time is observed with most catalysts (and particularly those containing vanadium which is very sensitive to reduction). If two hours are often considered as enough to reach a steady state in laboratory microreactors, 1,000 hrs and more are currently needed in industrial reactors [15]. This equilibration period consists of a surface and bulk restructuring, the extent and characterization of which are not easy to examine. The active sites may have to face contradictory requirements as reducing and oxidizing sites are wanted to coexist, and 
sometimes, particularly in alkane oxidation, these requirements cannot be easily met. Therefore it is interesting to separate the reaction step from the catalysts regeneration step [16]. This was soon understood for propene oxidation to acrolein [17], but put in practice only by DuPont researchers for the oxidation of n-butane to maleic anhydride in a circulating fluid bed reactor [18]. In such an assembly, which is close to that used in fluid catalytic cracking of oils, the main advantage is that the reaction step (oxidation of reactant and concomitant reduction of catalysts) is physically separated from the regeneration step (reoxidation of the catalyst), so that the operating conditions can be independently optimized [19]. This "redox decoupling" procedure can be performed with other devices, in which the two steps are spatially (e.g., catalytic membrane reactors) or timely (pulse or periodic feed reactors) separated. In the specific case of membrane reactors [20], the membrane may be inactive and just acts as a staged distributor of oxygen of the catalyst supported on it (e.g., $\mathrm{VMgO}$ on porous alumina membrane [21]). It may also be active and, in such cases, it generally exhibits mixed electronic oxide ion conductivity. Several of these conducting oxides can be used in the oxidative coupling of methane or the formation of syngas from methane at temperatures higher than $700^{\circ} \mathrm{C}[22,23,24]$. The first mild oxidation reaction studied was the oxidative dehydrodimerization of propene [25]. A bismuth lanthanum oxide was used as the oxide ion conducting catalyst, and the aim was to suppress electrophilic oxygen species on the surface and to avoid gas phase oxidation.

After first experiments on the above system in a catalytic dense membrane reactor (CDMR) [26,27], we have begun a study on the oxidation of $\mathrm{C}_{2}-\mathrm{C}_{3}$ hydrocarbons on BIMEVOX catalysts. These materials are the best oxide ion conductors at moderate temperature $\left(500-700^{\circ} \mathrm{C}\right)$, and their ionic conductivity is 100 -fold that of yttria-stabilised zirconia at $600^{\circ} \mathrm{C}[28,29]$. BIMEVOX acronym stands for oxides deriving from the Aurivillius structure of $\gamma-\mathrm{Bi}_{4} \mathrm{~V}_{2} \mathrm{O}_{11}$ by substituting part of Vanadium (and/or of BIsmuth) by a 
MEtallic cation [30]. Some BIMEVOX were tentatively used as powder catalysts $(\mathrm{ME}=\mathrm{Cu}$, Mn: $\mathrm{Bi}_{2} \mathrm{Cu}_{0.1} \mathrm{~V}_{0.9} \mathrm{O}_{5.35}$ and $\mathrm{Bi}_{2} \mathrm{Mn}_{0.1} \mathrm{~V}_{0.9} \mathrm{O}_{5.35}$, respectively) in fixed bed reactors in the oxidative coupling of methane and oxidative dehydrogenation (ODH) of propane [31], and $\mathrm{Bi}_{2} \mathrm{Cu}_{0.1} \mathrm{~V}_{0.9} \mathrm{O}_{5.35}$ and $\mathrm{Bi}_{2} \mathrm{Co}_{0.1} \mathrm{~V}_{0.9} \mathrm{O}_{5.35}$ in the oxidative dehydrodimerization of propene $[32,33]$. In this paper, the behaviour of surface unpolished membranes of $\gamma-\mathrm{Bi}_{2} \mathrm{VO}_{5.5}$ doped by $\mathrm{Co}, \mathrm{Cu}$ and $\mathrm{Ta}$ in the oxidation of propene and of propane using the CDMR assembly will be described. One of the most striking results is the formation of syngas, which was not observed in our former work concerning mirror-polished BICUVOX and BICOVOX membranes [34]. The role of semi-permeability to oxygen as compared to that of oxide ion conductivity will also be addressed to confirm that semi-permeability to $\mathrm{O}_{2}$ is not a key-point in selective oxidation.

\section{Experimental}

\subsection{Synthesis of catalysts and catalytic membranes}

Polycrystalline samples of BIMEVOX $\left(\mathrm{Bi}_{2} \mathrm{Me}_{0.1} \mathrm{~V}_{0.9} \mathrm{O}_{5.35}\right.$ with $\mathrm{Me}=\mathrm{Co}, \mathrm{Cu}$, and $\left.\mathrm{Bi}_{2} \mathrm{Ta}_{0.2} \mathrm{~V}_{0.8} \mathrm{O}_{5.5}\right)$ were prepared by heating a mixture of oxides $\left(\mathrm{Bi}_{2} \mathrm{O}_{3}, \mathrm{~V}_{2} \mathrm{O}_{5}, \mathrm{Me}_{\mathrm{x}} \mathrm{O}_{\mathrm{y}}\right)$ with appropriate stoichiometry at $600^{\circ} \mathrm{C}$ in air; after grinding, the powder was calcined at $850^{\circ} \mathrm{C}$ for 20 hours in a gold crucible. The purity of samples was checked by XRD according to reference patterns $[35,36]$. The specific surface area of the powders determined by B.E.T. method was $0.2-0.6 \mathrm{~m}^{2} / \mathrm{g}$ for all samples.

The powders of BIMEVOX were shaped as cylindrical membranes $(\varnothing=15 \mathrm{~mm}, 1.5 \mathrm{~mm}$ thickness) by uniaxial followed by isostatic pressing (150-180 MPa). The relative density as compared to the theoretical one was higher than $95 \%$. Each membrane was sintered at $750^{\circ} \mathrm{C}$ except BITAVOX which required a higher temperature $\left(875^{\circ} \mathrm{C}\right)$. Both sides of the membranes 
were "mirror" polished using a 4000 grit SiC paper, and then "depolished" with 200 grit SiC paper. Their surfaces were analysed before and after experiments by XRD, scanning electron microscopy (SEM), laser Raman spectroscopy (LRS) and X-ray photoelectron spectroscopy (XPS).

\subsection{Catalytic Dense Membrane Reactor (CDMR)}

Details of the assembly made up of the catalytic dense membrane reactor fed by mass flow controlled gases and on-line analysis of effluents using a mass spectrometer (Pfeiffer, Omnistar Prisma200) and/or oxygen gauge (Setnag, JC48V) may be found in [34]. The CDMR consists of the membrane sealed by means of Pyrex rings into two mullite tubes, which are inserted in a larger alumina tube flushed with nitrogen. A schematic is shown on Fig. 1. Gases were supplied to each compartment, respectively $\mathrm{O}_{2} / \mathrm{He}$ in the "high" oxygen partial pressure (HOP) or retentate side, and Ar in the "low" oxygen partial pressure (LOP) or permeate side for oxygen permeation measurements, or hydrocarbon/He for catalytic activity measurements. All gases (propene or propane) introduced in the LOP side contained less than 1 ppm $\mathrm{O}_{2}$ as impurity. The $\mathrm{CDMR}$ was operated at $\mathrm{T}=550-750^{\circ} \mathrm{C}$, contact time $\tau=2.3 \mathrm{~s}$, hydrocarbon to helium ratio $\mathrm{HC} / \mathrm{He}=1 \%(\mathrm{LOP})$, oxygen partial pressure $\mathrm{pO}_{2}=1$ to $10^{5} \mathrm{~Pa}$ (HOP) and flow rates $\mathrm{F}=50 \mathrm{~cm}^{3} / \mathrm{min}$ on both sides.

The polarization between the membrane surfaces was in situ determined by measuring the electric potential (Solid Electrolyte Potentiometry) [37] between two gold electrodes, a grid stuck on the HOP side as the counter electrode and a tip on the LOP side as the working electrode [34].

The protocole consisted of first measuring the flow of oxygen $\mathrm{J}_{\mathrm{O} 2}$ permeating from $\mathrm{HOP}$ to LOP at given temperature and contact time. Then the diluted hydrocarbon was flowed into LOP compartment in the same conditions of temperature and the catalytic properties were studied.. 


\section{Results}

\subsection{Catalytic properties of mirror-polished BICUVOX and BICOVOX membranes during oxidation of propene}

The main results obtained with air in HOP on mirror-polished BICUVOX and BICOVOX membranes during the oxidation of propene are summarized in Table 1. The conversion (X) of propene was low $(\mathrm{X} \leq 2.0 \mathrm{~mol} \%)$ and products of selective oxidation (hexadiene, benzene and acrolein) were formed. However, most of the converted propene resulted in carbon monoxide while very little or no $\mathrm{CO}_{2}$ was formed on BICUVOX or BICOVOX, respectively (Table 1). The formation of $\mathrm{CO}$ as the main product had already been observed when working on BIMEVOX powders in a conventional packed bed reactor, but at higher conversion (18-20 mol\%) and temperature $300-550^{\circ} \mathrm{C}[32,33]$. Little change was observed when the contact time in the CDMR increased from 2 to 12 s:the conversion increased, but the selectivity to CO also increased at the expense of mild oxidation products. On the contrary, the variation of the partial pressure of oxygen in HOP brought about more differences in the selectivity to products. The main modification was found when pure oxygen was replacing air (Table 2). The influence of the ME dopant can here be illustrated, because when $\mathrm{pO}_{2}$ increases, the selectivity to $\mathrm{CO}$ decreases in the case of BICOVOX, while it increases in the case of BICUVOX at the same low conversion $(\mathrm{X}=0.4-0.6 \mathrm{~mol} \%)$. The selectivity to mild oxidation products follows the reverse trend of selectivity to $\mathrm{CO}$.

The rate of permeation to oxygen expressed as $\mathrm{JO}_{2}$, the oxygen flux from the retentate (HOP) to the permeate (LOP) side, is low in the absence of reaction. In the temperature range $600-680^{\circ} \mathrm{C}$, it amounts to $3 \cdot 2 \cdot 10^{-4}-3 \cdot 1 \cdot 10^{-5} \mu \mathrm{mol} . \mathrm{cm}^{-2} \mathrm{~s}^{-1}$ for BICOVOX and is in the same range for BICUVOX. This amount does not account for the observed propene conversion: to 


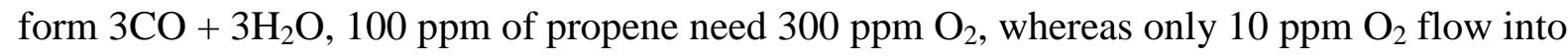
LOP in the absence of hydrocarbon. Therefore, the oxygen transfer to the membrane surface is strongly enhanced in the presence of hydrocarbon in the gas phase. The same experiments were performed with a mirror-polished erbium-doped bismuth oxide to which $40 \%$ silver was added (cermet) $[34,38]$. The oxygen flux was far higher (at $600-680^{\circ} \mathrm{C}, \mathrm{JO}_{2}=0.063-0.025$ $\left.\mu \mathrm{mol} . \mathrm{cm}^{-2} \mathrm{~s}^{-1}\right)$ than with BIMEVOX. However, the propene conversion remained as low $\left(\mathrm{X}_{\max }\right.$ $=1.2 \mathrm{~mol} \%$ ), and more $\mathrm{CO}_{2}$ was formed. Therefore, a high flux of oxygen permeating through the membrane to form $\mathrm{O}_{2}$ (in the absence of reactant) is not a key parameter as far as selective oxidation is concerned.

Pieces of both sides of the used membranes were analysed by SEM, XRD and XPS. Except a slight increase of the size of domains by $30-40 \%$ (SEM), analyses of the bulk (XRD) revealed no noticeable change. In the case of BICOVOX, the initial stoichiometry measured by XPS was recovered after experiments, which indicates that the stability of the membrane is good.

\subsection{Polarisation of mirror-polished membranes during catalysis with propene}

Solid Electrolyte Potentiometry [37] was performed during reaction with propene. In the case of BICUVOX, for example, the potential E, measured between the two sides of the membrane, was low and amounted to $-9.5 \mathrm{mV}$ before propene was fed. As soon as the hydrocarbon was fed, $|\mathrm{E}|$ slightly increased in few seconds and then it reached a steady value. By using the Nernst equation, a theoretical (thermodynamic) potential $\mathrm{E}_{\mathrm{th}}=-260 \mathrm{mV}$ would be expected for $\mathrm{pO}_{2}(\mathrm{LOP})=3 \mathrm{ppm}\left(\mathrm{O}_{2}\right.$ as an impurity in the helium gas cylinder). Conversely, a mean potential of $\mathrm{E}=-9.5 \mathrm{mV}$ results in $\mathrm{pO}_{2}(\mathrm{LOP})=0.13 .10^{5} \mathrm{~Pa}$ at the LOP membrane surface. Although these values stand only for the thermodynamic equilibrium state and in the absence of any reactant, they give an idea of the actual activity of oxygen on LOP 
side. All proceeds as if plenty of oxygen species on LOP surface would be available for the hydrocarbon to react. The reaction provides an alternative pathway for oxygen extraction in place of the rate-limiting recombination of $\mathrm{O}^{2-}$ to $\mathrm{O}_{2}$.

\subsection{Catalytic oxidation of propene on depolished BIMEVOX membranes}

The behaviour of depolished BIMEVOX $(\mathrm{ME}=\mathrm{Cu}, \mathrm{Co}$, Ta) membranes was studied in the same conditions as above. As expected, the activity was far higher than with polished membranes but transient phenomena occurred. Depending on ME, the conversion of propene goes through a more or less sharp maximum $\left(\mathrm{X}_{\mathrm{Ta}}: 70>\mathrm{X}_{\mathrm{Cu}}: 53>\mathrm{X}_{\mathrm{Co}}: 40 \mathrm{~mol} \%\right)$ at times $t$ following the reverse trend $\left(t_{\mathrm{Ta}}: 130<t_{\mathrm{Cu}}: 180<t_{\mathrm{Co}}: 220 \mathrm{~s}\right.$ ) (Figs. 2, 3 and 4 for $\mathrm{ME}=\mathrm{Co}, \mathrm{Cu}$ and Ta, respectively). The partial pressure of products decreases along $\mathrm{p}_{\mathrm{H} 2}>\mathrm{p}_{\mathrm{CO}}>\mathrm{p}_{\mathrm{CO} 2}>$ $\mathrm{p}_{\mathrm{CH} 4}$, with $\mathrm{H}_{2} / \mathrm{CO}=1.2$ (Ta) to $1.7(\mathrm{Co}, \mathrm{Cu})$, which is higher than the stoichiometric proportion for propene reaction to $\mathrm{CO}+\mathrm{H}_{2}\left(\mathrm{H}_{2} / \mathrm{CO}=1.0\right)$. Traces of acrolein and hexadiene were detected simultaneously to $\mathrm{CO}_{2}$ and $\mathrm{CH}_{4}$ during the very first minutes. Hydrogen remained the main product for the whole experiment but carbon was recovered in the LOP side of the reactor after the transient peak. This carbon was burnt by substituting $\mathrm{O}_{2} / \mathrm{He}\left(\mathrm{pO}_{2}=\right.$ $0.21 .10^{5} \mathrm{~Pa}$ ) to propene/He in the LOP compartment for few hours. By this means, most active sites were regenerated, which indirectly showed that the membrane had retained its structural integrity. Indeed, quite the same figures (conversion, distribution and amounts of products) were recovered by feeding again propene.

\subsection{Catalytic oxidation of propane on depolished BIMEVOX membranes}

Helium-diluted propane ( $1 \%$ ) and air were fed into LOP and HOP, respectively, to study the performance of $\mathrm{Cu}, \mathrm{Co}$ and Ta-doped bismuth vanadates. Transient behaviours were again observed, but the activity peaks were delayed as compared to experiments with propene, in 
accordance with the lower reactivity of propane (Table 3). At first, the conversion was increasing for very short periods but it was very low $(X=1-2$ mol\%). Small amounts of propene due to the oxidative dehydrogenation of propane were detected, with co-production of $\mathrm{CO}_{2}$ and water. During the following period, the conversion was steady $(\mathrm{X}=12-28 \%)$ (steady state I) and syngas was formed for a time depending on ME in BIMEVOX (Table 3). The pressure of the main products $\left(\mathrm{H}_{2}>\mathrm{CO} \gg \mathrm{CH}_{4}, \mathrm{CO}_{2}\right.$ and water) increased during the fast increase of conversion. After the activity peak (which was double for BICOVOX), hydrogen was produced in larger amounts while $\mathrm{CO}$ decreased at the profit of coke for a long and steady period (steady state II). For all three membranes, $\mathrm{H}_{2} / \mathrm{CO}$ reached the same value (ca. 2.0) for a short $\left(t_{\mathrm{Ta}}: 100 \mathrm{~s}\right)$ to longer $\left(t_{\mathrm{Cu}}: 5.2 \mathrm{mn} ; t_{\mathrm{Co}}: 21 \mathrm{mn}\right)$ time (Fig. 5 for BICOVOX). As $\mathrm{H}_{2} / \mathrm{CO}=1.33$ for the stoichiometric oxidation of $\mathrm{C}_{3} \mathrm{H}_{8}$ to $3 \mathrm{CO}+4 \mathrm{H}_{2} \mathrm{O}$, other reactions proceed probably in the same time. Later, $\mathrm{H}_{2} / \mathrm{CO}=3.0-3.2$ is obtained at $260 \mathrm{~s}$ for Ta and at $1780 \mathrm{~s}$ for $\mathrm{Co}$. In the case of $\mathrm{Cu}$ membrane this value is steady from $t=450 \mathrm{~s}$. By replacing air by pure oxygen in HOP, similar phenomena were observed. The most striking effect is exerted on the activity peak(s) (Table 3), which is delayed (Co) (Fig. 5) or slightly advanced $(\mathrm{Cu})$ [39], or quite not modified (Ta). The polarisation curve follows an inverse trend as compared to that of the conversion, as shown for BITAVOX on Fig. 6. The theoretical partial pressure of oxygen on LOP side calculated by the Nernst equation is high $\left(\mathrm{p}_{\mathrm{O} 2 \mathrm{th}} \sim 9.10^{3} \mathrm{~Pa}\right.$ at the maximum of activity peak). As already noted in the case of propene oxidation, the production of $\mathrm{CO}$ cannot be accounted for by the amount of oxygen that would permeate through the membrane because it is far too small. Therefore, even in these strongly reducing conditions, the polarisation is high enough and the membrane is still active.

\section{Discussion}

\subsection{Solid state characteristics of BIMEVOX}


Three polymorphs $\alpha, \beta$ and $\gamma$ are known for $\mathrm{Bi}_{4} \mathrm{~V}_{2} \mathrm{O}_{11}$ which undergoes two successive phase transitions $\alpha \rightarrow \beta$ and $\beta \rightarrow \gamma$ at $c a .380$ and $530^{\circ} \mathrm{C}$, respectively. Their crystal structures can be described in an orthorhombic "mean" cell, with $\mathrm{a}_{\mathrm{m}} \sim 5.53, \mathrm{~b}_{\mathrm{m}} \sim 5.61$ and $\mathrm{c}_{\mathrm{m}} \sim 15.28 \AA$. The $\alpha$ and $\beta$ forms are superstructures with $\mathrm{a} \sim 6 \mathrm{a}_{\mathrm{m}}$ and $\mathrm{a} \sim 2 \mathrm{a}_{\mathrm{m}}$. The structure of $\gamma-\mathrm{Bi}_{4} \mathrm{~V}_{2} \mathrm{O}_{11}$ (tetragonal with $\mathrm{a} \sim \sqrt{ } 2 / 2 \mathrm{a}_{\mathrm{m}}$ ) which, as $\mathrm{Bi}_{2} \mathrm{MoO}_{6}$, is the simplest example of Aurivillius compounds $[40,41]$, can be described as alternating pyramidal $\left[\mathrm{Bi}_{2} \mathrm{O}_{2}\right]^{2+}$ and perovskite like $\left[\mathrm{VO}_{3.5} \square_{0.5}\right]^{2-}$ (where $\square$ is an ion oxide vacancy) layers (Fig. 5). The Me cation substitutes vanadium in most cases but Bi may also be partly replaced $[28,30,35,36]$. The role of defects is prominent to explain the high oxide ion conductivity of these bismuth vanadates stabilised at room temperature. A proposed conduction mechanism for divalent ME-substituted BIMEVOX [28,29,42-44] involves positional exchange of oxide ions and vacancies in the vanadate layers and results in the two-dimensional oxide ion conduction mechanism. This is allowed by the versatility of vanadium whose coordination easily varies from 6 to 4 -fold, this feature being also known as an important factor of activity in oxidation catalysis. A second important factor is the presence of the Bi lone pair of electrons which is stereochemically active and points to vacant sites between four corner-sharing vanadium polyhedra. The polarizability of the Bi lone pair is responsible for a kind of "racket" effect exerted on the oxygen which hops from one vacancy to the other (Fig. 8). Neutron diffraction data revealed a large atomic disorder in vanadium layer around the apical $\mathrm{O}(2)$ and equatorial $\mathrm{O}(3)$ oxygen sites which are partly occupied $[42,43]$. The barrier energies for the oxygen diffusion can be calculated from the Joint Probability Density Function (JPDF) by considering the anharmonic thermal motion in $\gamma-\mathrm{Bi}_{4} \mathrm{~V}_{2} \mathrm{O}_{11}$ structure. Fig. 8 shows the JPDF map of oxygen in a section defined by $\mathrm{O}(2), \mathrm{O}(3)$ and the vanadium position. Pseudo-potential were derived and the lowest energy barrier was obtained for the diffusion of an oxide from an apical site $\mathrm{O}(2)$ to an 
equatorial $\mathrm{O}(3)$ site with a barrier of $0.2 \mathrm{eV}$, in good agreement with the activation energy measured for this $\gamma$-polymorph at high temperature by impedance spectroscopy $[29,45]$.

BICUVOX exhibits the highest oxide ion conduction at moderate temperature (Fig. 9). The reason why is not exactly known. The ionic radius for 6-fold coordination [46] decreases along $\mathrm{Zn}^{2+}(0.74)>\mathrm{Cu}^{2+}(0.73)>\mathrm{Ni}^{2+}(0.69)>\mathrm{Co}^{2+}(0.65)>\mathrm{Ta}^{5+}(0.64 \AA)$, while that of $\mathrm{V}^{5+}$ is $0.54 \AA$. The value of ionic radius closest to that of $\mathrm{V}^{5+}$ is $0.57 \AA$ for $\mathrm{Cu}^{2+}$ in its common square planar coordination due to the Jahn-Teller effect. Both value and coordination of $\mathrm{Cu}^{2+}$ are probably related to the highest ion conductivity which is exhibited by BICUVOX as compared to BICOVOX or others.

\subsection{Catalytic vs. structural properties}

The three BIMEVOX samples studied as dense membranes in the oxidation of propene and of propane behave similarly. The polarisation E between the LOP and HOP sides, which depends on the contact time, follows exactly the reverse trend of the conversion curves. As E is always very high compared to the theoretical value, it means that a large amount of $\mathrm{O}^{2-}$ specie is available in LOP side for the reaction to proceed. Experiments were recently performed by one of us by means of ${ }^{18} \mathrm{O} /{ }^{16} \mathrm{O}$ isotopic exchange followed by SIMS [47]. The oxygen transport in an oxide ion conductor material proceeds by the oxygen exchange $\left(\mathrm{O}_{2}+\right.$ $4 \mathrm{e} \leftrightarrow 2 \mathrm{O}^{2-}$ ) at the surface, followed by the diffusion of $\mathrm{O}^{2-}$ through the material. Whereas the diffusion coefficient D of BIMEVOX $(\mathrm{ME}=\mathrm{Cu}, \mathrm{Co}, \mathrm{Bi})$ amounts to 3 to $8.10^{-7} \mathrm{~cm}^{2} / \mathrm{s}$, which is by one order of magnitude higher than that in common oxide electrolytes like YSZ or cerium-doped gadolinium oxide $\left(D \approx 2-4 \cdot 10^{-8} \mathrm{~cm}^{2}\right.$ ), the surface exchange coefficient $k$ is in the same order of magnitude $\left(k=0 \cdot 2-1 \cdot 2 \cdot 10^{-8}\right.$ vs. $6 \cdot 10^{-9}$ and $6 \cdot 10^{-8} \mathrm{~cm} / \mathrm{s}$, respectively).

Particularly, the recombination step of $\mathrm{O}^{2-}$ to $\mathrm{O}_{2}$ is very slow, and this rate-limiting process accounts for the high polarisation measured between the LOP and HOP surfaces. In the case 
of combustion reactions like those proceeding in SOFC, all electrophilic and nucleophilic $\left(\mathrm{O}_{2}^{2-}, \mathrm{O}_{2}^{-}, \mathrm{O}^{-}, \mathrm{O}^{2-}\right)$ types of oxygen specie are useful to totally oxidize the reactant. On the contrary, in selective oxidation catalysis, the presence of $\mathrm{O}_{2}$ permeating to LOP is to be avoided, otherwise the formation of $\mathrm{CO}_{2}$ would be promoted. As we have demonstrated, BIMEVOX materials are therefore convenient because the rate of $\mathrm{O}_{2}$ permeation is very low.

The regime and the products observed during oxidation of propene or propane depend on the surface roughness of the membranes. When the surface is "mirror-polished", few active sites are present. However the estimated turn-over number in the oxidation of propene is ca.1-10 s ${ }^{-1}$, values which are close to those of usual oxidation catalysts. During the steady regime at low conversion $(\mathrm{X}<2.5 \mathrm{~mol} \%) \mathrm{CO}$ is predominantly formed besides hexadiene, benzene and acrolein (and water). The formation of these products requires far more oxygen species than those permeating but the material properties are not modified by the reaction. It means that the function of the CDMR is carried out: the rate of oxidation of propene being smaller than the rate of diffusion of $\mathrm{O}^{2-}$ from $\mathrm{HOP}$, numerous enough $\mathrm{O}^{2-}$ species diffuse to ensure the replenishment of vacancies created by the reaction in LOP side. When the surface roughness increases (“depolished" surfaces) the rate of reaction increases also, but the rate of $\mathrm{O}^{2-}$ diffusion is still the same at a same given temperature. Several steps are now noticed. At the very first seconds, the conversion of propene is low $(\mathrm{X} \leq 2 \mathrm{~mol} \%)$ as when the surface was not rough, and the distribution of products of selective (hexadiene, acrolein) and partial (CO) oxidations is similar. Later $\mathrm{CO}$ and $\mathrm{H}_{2}$, and then $\mathrm{C}$ and $\mathrm{H}_{2}$ are predominantly formed during and after the activity peak. The reactions are slower in the case of propane oxidation. At the beginning, the conversion is low and propene is formed by ODH. Then a steady regime is settled and is held on as long as a certain amount of $\mathrm{O}^{2-}$ is available because of the high polarisation of LOP surface. During this steady state I (Table 3), hydrogen and CO are the main products and the $\mathrm{H}_{2} / \mathrm{CO}$ ratio is constant (2.0-2.2 vs. 1.33 for stoichiometry). When the 
(sub)surface is oxygen depleted, a restructuration of the surface probably occurs which leads to a strong increase of conversion. The increase in $\mathrm{CO}$ production is slower than that of $\mathrm{H}_{2}$ because less $\mathrm{O}^{2-}$ are available. $\mathrm{P}_{\mathrm{CO}}$ follows exactly the conversion curve for a while but it decreases before the activity has reached its maximum. We suppose that during this step the rate of $\mathrm{O}^{2-}$ diffusion is not high enough, hence the conversion decreases by lack of oxygen which favours the cracking of propane and the formation of carbon deposits. A new steady state (steady state II) is reached, during which the main products are hydrogen and carbon. However, $\mathrm{CO}$ keeps on producing at conversion values which are very close to those in steady state $\mathrm{I}(\mathrm{X} \approx 10 \mathrm{~mol} \%)$. It seems therefore that sites for partial oxidation similar to those available in the beginning are still present, or that they are continuously regenerated. This assumption is reasonable because the various steps are again proceeding after burning the carbon and flowing propane again.

Although the sequence of events is similar for all BIMEVOX, the phenomena happen at different times according to the doping metal $(\mathrm{Cu}, \mathrm{Co}, \mathrm{Ta})$. As the conversions, as well as the $\mathrm{H}_{2} / \mathrm{CO}$ ratios, go exactly through the same values whatever ME, it means, at least in first approximation, that the number of active sites and the mechanism also are similar. Moreover, as the permeation rate (in the absence of reaction) is in the same range for these materials, the rates of reduction of $\mathrm{O}_{2}$ at $\mathrm{HOP}$ surface and of $\mathrm{O}^{2-}$ diffusion through the membrane are also assumed to bethe same. It is interesting to note that, although the ionic conductivity $\sigma_{\mathrm{i}}$ of BICUVOX is slightly higher than that of other BIMEVOX (Fig. 9), its catalytic properties do not vary in proportion. The only property which varies with ME is the electron conductivity $\sigma_{\mathrm{e}}$. Co and $\mathrm{Cu}$ doping leads to p- and n-type electronic conductivity, respectively [48], whereas BITAVOX is n-type, if not neutral, because $\sigma_{\mathrm{e}}$ is very small [49]. The electron conductivity $\sigma_{\mathrm{e}}$ modifies not only the step of reduction of $\mathrm{O}_{2}$ to $\mathrm{O}^{2-}$ which was shown to be rate limiting [47], but also the $\mathrm{O}^{2-}$ diffusion rate itself as electrons must flow in the reverse 
sense to ensure electroneutrality. This is illustrated by the modifications of behaviour observed when the partial pressure of oxygen in the HOP side was varied. Table 2 shows that, upon increasing $\mathrm{pO}_{2} \mathrm{HOP}$ from $2.10^{2}$ to $10^{5} \mathrm{~Pa}$ during the oxidation of propene, the selectivity to $\mathrm{CO}$ decreases or increases (products of selective oxidation increasing or decreasing) with mirror-polished BICOVOX and BICUVOX, respectively. Modifications in the sequence of steps are observed on depolished membranes in the presence of propane by feeding HOP with $\mathrm{O}_{2}$ instead of air (Table 3). The duration of steady state I characterized by the production of syngas is extended on BICOVOX, shortened on BICUVOX and quite unchanged on BITAVOX. With increasing $\mathrm{pO}_{2}$, the conductivity $\sigma_{\mathrm{e}}$ increases for $\mathrm{p}$-type and decreases for ntype semiconductors $[11,12]$. Consequently, in the case of p-type BICOVOX, both surface exchange and diffusion rates should be enhanced by increase of $\mathrm{pO}_{2}$ in $\mathrm{HOP}$, thereby producing more oxygen species to oxidize propane to syngas, and delaying the surface restructuring which leads to coking. The same explanation holds for the oxidation of propene on mirror-polished BICOVOX membrane because products of selective oxidation increase (Table 2). In the same conditions, the n-type conductivity of BICUVOX would be responsible for the acceleration of surface restructuring (depolished membranes with propane), or for the increase in selectivity to $\mathrm{CO}$ (mirror-polished membrane with propene), whereas BITAVOX performance is poorly affected.

\section{Conclusion}

Owing to the large possibility of vanadium-substituted $\gamma-\mathrm{Bi}_{4} \mathrm{~V}_{2} \mathrm{O}_{11}$ materials, the BIMEVOX family offers an opportunity to examine the influence of the metallic cation ME on catalytic properties while keeping the same crystal structure. The oxide ion conductivity is very high, even at low temperature, but the semi-permeability to molecular oxygen is poor because the oxygen exchange $\mathrm{O}_{2} \leftrightarrow \mathrm{O}^{2-}$ at the surface is rate-limiting. The defects (oxygen 
vacancies, variable coordination) affect mainly the vanadium layers and depend on the valence and coordination of ME, although it is still difficult to know to what extent. Using these materials as catalytic dense membranes in redox decoupling conditions (CDMR) provides another view of their advantages and drawbacks. The delivery of oxygen specie $\left(\mathrm{O}^{2-}\right)$ which are needed for the oxidation reaction depends on both $\mathrm{O}^{2-}$ diffusion which is fast and on surface reduction of $\mathrm{O}_{2}$ which is slow. The latter depends on the electronic properties which are revealed mainly when the oxygen partial pressure is modified on the HOP side.

Two divalent $(\mathrm{Co}, \mathrm{Cu})$ and one pentavalent $(\mathrm{Ta})$ dopants were chosen and the resulting BIMEVOX used as catalytic dense membranes in the oxidation of propene and of propane. Although potentially active sites are plural as three cations $(\mathrm{Bi}, \mathrm{V}, \mathrm{Me})$ are present, their catalytic behaviour is very similar when the surface roughness is (approximately) the same. A steady regime, characterized by a low conversion of propene and the formation of mild oxidation products (acrolein, hexadiene, $\mathrm{CO}$ ), or of partial oxidation products $\left(\mathrm{CO}\right.$ and $\left.\mathrm{H}_{2} \mathrm{O}\right)$, was observed with smooth surfaces. Transient phenomena were observed with rougher surfaces, but the type, the distribution and the amount of products (propene or syngas in the case of propane), were similar for all three BIMEVOX. Therefore, the role of ME which is more $(\mathrm{Cu})$, or less $(\mathrm{Co}, \mathrm{Ta})$ reducible, does not seem prominent, and bismuth and/or vanadium are undergoing reduction when necessary. The analyses of the mirror-polished membranes showed that the bulk, but also the LOP and HOP surfaces, were not strongly modified, which could be related to the low conversion $(\mathrm{X}<2.5 \%)$. However strong modifications were also not observed on depolished BITAVOX membranes, although they experienced strong variations of conversion in highly reducing atmosphere (propane, $\mathrm{H}_{2}, \mathrm{CO}$ in LOP). In particular, no metallic bismuth nor bismuth oxide could be identified by XRD on the reaction side surface. This stability accounts for the fact that the initial state can be restored after coke has been burnt. Finally, the difference of reactivity vs. time observed for the three membranes 
with the same driving force (same partial pressure of $\mathrm{O}_{2}$ on HOP side) was emphasized by modifying that pressure. It follows that electronic properties which depend on ME, although they are poor as compared to those of mixed ionic and electronic conductors oxides, influence the step of $\mathrm{O}_{2}$ reduction. Several means are under study to stabilize the production of syngas, or alternatively the ODH of propane, but analyses are also in progress to get a better understanding of the phenomena, particularly of the reversible surface restructuration.

\section{Acknowledgements}

The Centre National de la Recherche Scientifique, the Chevreul Federation (CNRS) and the Région Nord-Pas de Calais are acknowledged for providing a grant to one of the authors (H.B.) and for financial support. Part of this work was performed in the frame of CONCORDE "Coordination of Nanostructured Catalytic Oxide Research and Development in Europe", an European Union funded concerted action ( $6^{\text {th }}$ Framework Programme). 


\section{References}

[1] J. Mars and D.W. van Krevelen, Chem. Eng. Sci, Special Suppl. 3 (1954) 41.

[2] F.F. Wolkenstein, The Electronic Theory of Catalysis on Semiconductors, Pergamon Press, Oxford(1963).

[3] F.S. Stone, J. Solid State Chem. 12 (1975) 271.

[4] R.K. Grasselli and J.L. Callahan, J. Catal. 14 (1969) 93.

[5] R.K. Grasselli, D.D. Suresh, K. Knox, J. Catal. 18 (1970) 356.

[6] J. Haber, in: Perspectives in Catalysis, J.M. Thomas and K.I. Zamaraev Eds, Blackwell Sci. Pub. Oxford, 1992.

[7] P. Courtine, ACS Symp. Series 279 (1985) 37.

[8] J.E. Germain, Catalytic Conversion of Hydrocarbons, Academic Press, New York, 1969.

[9] R.K. Grasselli and J.F. Brazdil (Eds.), Solid State Chemistry in Catalysis, ACS Symp. Series No. 279, American Chemical Society, Washington DC(1985). Papers therein.

[10] C. Doornkamp, M. Clement, V. Ponec, J. Catal. 182 (1999) 390.

[11] P.J. Gellings and H.J.M. Bouwmeester, Catal. Today 58 (2000) 1.

[12] P.J. Gellings and H.J.M. Bouwmeester (Eds.), The CRC Handbook of Solid State Electrochemistry, CRC Press, Boca Raton(1997).

[13] H. Ponceblanc, J. M. M. Millet, G. Coudurier, J.M. Herrmann, J. C. Vedrine, J. Catal. 142 (1993) 373.

[14] E.V. Kondratenko, D. Wolf and M. Baerns, Catal. Lett. 58 (1999) 217.

[15] F. Cavani, F. Trifirò, P. Arpentinier, The Catalytic Technology of Oxidation. Technip, Paris, 2001.

[16] E. Bordes and R.M. Contractor, Topics Catal. 3 (1996) 365.

[17] R. DiCosimo, J.D. Burrington and R.K. Grasselli, US Pat. 4571443 (1986)

[18] R.M. Contractor, H.E. Bergna, H.S. Horowitz., C.M. Blackstone, U. Chowdry, A.W. Sleight, Surf. Sci. Catal. 38 (1987) 645.

[19] E. Bordes-Richard, L'Actualité Chimique, mai-juin (2002) 38.

[20] J.A. Dalmon, in G. Ertl, H. Knözinger, J. Weitkamp (Eds.), Handbook of Heterogeneous Catalysis, VCH-Wiley(1997) chapter 9.3.

[21] M.J. Alfonso, M. Menendez, J. Santamaria, Chem. Eng. J. 90 (2002) 131.

[22] U. Balachandran, J.T. Dusek, P.S. Maiya, B. Ma, R.L. Mieville, M.S. Kleefish, C.A. Udovich, Catal. Today 36 (1997) 265. 
[23] J.E. ten Elshof, H.J.M. Bouwmeester, H. Verweij, Appl. Catal. A: General 30 (1995) 195.

[24] A. Julbe, D. Farrusseng, C. Guizard, Catal. Today 104 (2005) 102.

[25] R. Di Cosimo, J.D. Burrigton, R. Grasselli. K, J. Catal. 102 (1986) 234.

[26] S. Azgui, F. Guillaume, B. Taouk and E. Bordes, Catal. Today 25 (1995) 291.

[27] C. Courson, B. Taouk, E. Bordes Catal. Lett. 66 (2000) 129.

[28] G. Mairesse, in 'Fast Ion transport in Solids', B. Scrosati et al. (Eds), Kluwer Academic Publishers (1993) 271.

[29] G. Mairesse, C.R. Acad. Sci., Paris, Serie IIc : Chimie 2 (1999) 651.

[30] S. Lazure, R.N. Vannier, G. Nowogrocki, G. Mairesse, C. Muller, M. Anne, P. Strobel, J. Mater. Chem. 5 (1995) 1395.

[31] A. Cherrak, R. Hubaut, Y. Barbaux, G. Mairesse, Catal. Lett. 15 (1992) 377.

[32] A. Chetouani, B. Taouk, E. Bordes-Richard, E. Abi-Aad, A. Aboukaïs, Appl. Catal. A : General 252 (2003) 269.

[33] A. Chetouani, B. Taouk, E. Bordes-Richard, Catal. Today 91-92C (2004) 75.

[34] A. Löfberg, S. Boujmiai, E. Capoen, M.C. Steil, C. Pirovano, R.N. Vannier, G. Mairesse, E. Bordes-Richard, Catal. Today 91-92C (2004) 81.

[35] F. Abraham, J.C. Boivin, G. Mairesse, G. Nowogrocki, Solid State Ionics 40-41 (1990) 934.

[36] S. Lazure, R.N. Vannier, G. Nowogrocki, G. Mairesse, C. Muller, M. Anne, P. Strobel, J. Mater. Chem. 5 (1995) 1395.

[37] C. Wagner, Adv. Catal. 21 (1970) 323.

[38] H.J.M. Bouwmeester, H. Kruidhof, A.J. Burgraaf and P.J. Gellings, Solid State Ionics 53-56 (1992) 460.

[39] A. Löfberg, C. Pirovano, M.C. Steil, R.N. Vannier, E. Bordes-Richard, Catal. Today 112 (2006) 8.

[40] B. Aurivillius, Arkiv Kemi 2 (1950) 519.

[41] A.F. van den Elzen and G.D. Rieck, Acta Crystallogr. Sect.B 29 (1973) 2436.

[42] P. Roussel, R.N. Vannier, M. Anne, G. Nowogrocki, Solid State Ionics, submitted.

[43] M. Anne, G. Nowogrocki and G. Mairesse. Acta Cryst. (2002) A58, C319

[44] I. Abrahams and F. Krok, Solid State Ionics 157 (2002) 139.

[45] C. Pirovano, M.C. Steil, E. Capoen, G. Nowogrocki, R.N. Vannier, Solid State Ionics 176 (2005) 2079.

[46] R.D. Shannon, Acta Crystallog. A 32 (1976) 751. 
[47] R.N. Vannier, S.J. Skinner, R.J. Chater, J.A. Kilner, G. Mairesse, Solid State Ionics 160 (2003) 85 .

[48] M. Guillodo, J. Fouletier, L. Dessemond and P. Del Gallo, Electrochim. Acta 47 (2002) 2809.

[49] C. Pirovano, A. Löfberg, H. Bodet, E. Bordes-Richard, M.C. Steil, R.N. Vannier, Solid State Ionics in press.. 


\section{Figure captions}

Fig. 1. Schematic representation of the catalytic dense membrane reactor

Fig. 2. Conversion of propene and partial pressure of products obtained at $650^{\circ} \mathrm{C}$ with BICOVOX (Air in HOP)

Fig. 3. Conversion of propene and partial pressure of products obtained at $650^{\circ} \mathrm{C}$ with BITAVOX (Air in HOP)

Fig. 4. Conversion of propene and partial pressure of products obtained at $650^{\circ} \mathrm{C}$ with BICUVOX (Air in HOP)

Fig. 5. Influence of $\mathrm{pO}_{2}$ in $\mathrm{HOP}$ on conversion of propane and $\mathrm{H}_{2} / \mathrm{CO}$ with BICOVOX

Fig. 6. Conversion of propane and electric potential measured at $675^{\circ} \mathrm{C}$ with BITAVOX; the equivalent pressure of oxygen evaluated by Nernst equation is indicated.

Fig. 7. Structure of $\gamma-\mathrm{Bi}_{4} \mathrm{~V}_{2} \mathrm{O}_{11}$

Fig. 8. Vanadate layer. a) Coordination of vanadium (green for apical, red for equatorial oxygens); b) jpdf map showing the distribution of electron contour [42].

Fig. 9. Arrhenius diagram of oxide ion conductivity $\sigma_{i}$ vs. reciprocal temperature for YSZ, $\mathrm{Bi}_{4} \mathrm{~V}_{2} \mathrm{O}_{11}$, BIMEVOX.10 $\left(\mathrm{Bi}_{2} \mathrm{Me}_{0.1} \mathrm{~V}_{0.9} \mathrm{O}_{5.35}\right.$ with $\left.\mathrm{Me}=\mathrm{Co}, \mathrm{Cu}\right)$ and BITAVOX.20 $\left(\mathrm{Bi}_{2} \mathrm{Ta}_{0.2} \mathrm{~V}_{0.8} \mathrm{O}_{5.5}\right)$. 


\section{TABLES}

Table 1. Conversion of propene and selectivity to products for mirror-polished membranes of $\operatorname{BICOVOX}(\mathrm{Co})$ and BICUVOX $(\mathrm{Cu})$ as a function of temperature $\left(\mathrm{pC}_{3} \mathrm{H}_{6}=10^{3} \mathrm{~Pa}, \mathrm{pO}_{2} \mathrm{HOP}\right.$ $\left.=0.21 .10^{5} \mathrm{~Pa}\right)$.

\begin{tabular}{|c|c|c|c|c|c|c|c|c|c|c|}
\hline \multirow{2}{*}{$\begin{array}{l}\text { Temp. } \\
\left({ }^{\circ} \mathrm{C}\right) \\
\mathrm{Me}:\end{array}$} & \multicolumn{2}{|c|}{$\begin{array}{c}\text { Conv. X } \\
(\mathrm{mol} \%)\end{array}$} & \multicolumn{2}{|c|}{$\begin{array}{c}\mathrm{S}_{\mathrm{HXD}+\mathrm{BZ}} * \\
(\mathrm{~mol} \%)\end{array}$} & \multicolumn{2}{|c|}{$\begin{array}{l}\mathrm{S}_{\mathrm{ACO}} * \\
(\mathrm{~mol} \%)\end{array}$} & \multicolumn{2}{|c|}{$\begin{array}{c}\mathrm{S}_{\mathrm{CO}} \\
(\mathrm{mol} \%)\end{array}$} & \multicolumn{2}{|c|}{$\begin{array}{c}\mathrm{S}_{\mathrm{CO} 2} \\
(\mathrm{~mol} \%)\end{array}$} \\
\hline & $\mathrm{Co}$ & $\mathrm{Cu}$ & $\mathrm{Co}$ & $\mathrm{Cu}$ & $\mathrm{Co}$ & $\mathrm{Cu}$ & $\mathrm{Co}$ & $\mathrm{Cu}$ & Co & $\mathrm{Cu}$ \\
\hline 600 & 0.23 & 0.28 & 37.0 & 30.4 & 5.7 & 6.2 & 50.7 & 56.8 & 2.5 & 2.3 \\
\hline 625 & 0.33 & 0.35 & 38.4 & 27.1 & 9.2 & 9.1 & 43.5 & 55.8 & 2.0 & 2.4 \\
\hline 650 & 0.45 & 0.47 & 34.1 & 25.5 & 12.0 & 12.4 & 43.7 & 51.6 & 1.7 & 3.0 \\
\hline 675 & 0.79 & 0.80 & 24.7 & 22.3 & 11.2 & 15.5 & 53.9 & 48.7 & 1.9 & 5.0 \\
\hline
\end{tabular}

$* \mathrm{HXD}=1,5$-hexadiene; $\mathrm{BZ}=$ benzene; $\mathrm{ACO}=$ acrolein

Table 2. Conversion of propene and selectivity to products for mirror-polished membranes of BICUVOX and BICOVOX as a function of $\mathrm{pO}_{2}$ in $\mathrm{HOP}\left(\mathrm{pC}_{3} \mathrm{H}_{6}=10^{3} \mathrm{~Pa}, 675^{\circ} \mathrm{C}\right)$.

\begin{tabular}{|c|c|c|c|c|c|c|c|c|c|c|}
\hline \multirow{2}{*}{$\begin{array}{r}\mathrm{pO}_{2} \mathrm{HOP} \\
(\mathrm{Pa}) \\
\mathrm{Me}:\end{array}$} & \multicolumn{2}{|c|}{$\begin{array}{c}\text { Conv. X } \\
(\mathrm{mol} \%)\end{array}$} & \multicolumn{2}{|c|}{$\begin{array}{c}\mathrm{S}_{\mathrm{HXD}+\mathrm{BZ}}{ }^{*} \\
(\mathrm{~mol} \%)\end{array}$} & \multicolumn{2}{|c|}{$\begin{array}{c}\mathrm{S}_{\mathrm{ACO}} * \\
(\mathrm{~mol} \%)\end{array}$} & \multicolumn{2}{|c|}{$\begin{array}{c}\mathrm{S}_{\mathrm{CO}} \\
(\mathrm{mol} \%)\end{array}$} & \multicolumn{2}{|c|}{$\begin{array}{c}\mathrm{S}_{\mathrm{CO} 2} \\
(\mathrm{~mol} \%)\end{array}$} \\
\hline & Co & $\mathrm{Cu}$ & Co & $\mathrm{Cu}$ & Co & $\mathrm{Cu}$ & Co & $\mathrm{Cu}$ & Co & $\mathrm{Cu}$ \\
\hline $2.10^{2}$ & 0.34 & 0.68 & 16.1 & 19.5 & 8.0 & 13.9 & 67.7 & 53.9 & 2.6 & 5.3 \\
\hline $2.10^{3}$ & 0.41 & 0.58 & 19.9 & 16.7 & 9.7 & 9.6 & 61.3 & 64.2 & 2.1 & 3.9 \\
\hline $21.10^{4}$ & 0.35 & 0.61 & 26.3 & 16.1 & 12.8 & 6.1 & 48.2 & 72.3 & 3.8 & 1.6 \\
\hline $10^{5}$ & 0.37 & 0.66 & 22.4 & 6.2 & 10.4 & 1.8 & 59.8 & 89.5 & 1.4 & 1.1 \\
\hline
\end{tabular}

* HXD: 1,5-hexadiene; BZ: benzene; ACO: acrolein 
Table 3. Oxidation of propane using depolished BIMEVOX $(\mathrm{ME}=\mathrm{Cu}, \mathrm{Co}$, Ta $)$ membranes and influence of $\mathrm{pO}_{2}$ in $\mathrm{HOP}$ (air: $0.21 .10^{5}$ or $\mathrm{O}_{2}: 10^{5} \mathrm{~Pa}$ ) at $675^{\circ} \mathrm{C}$

\begin{tabular}{lccccccccc}
\hline & \multicolumn{3}{c}{ Steady state I } & \multicolumn{3}{c}{ Maximum of activity } & \multicolumn{3}{c}{ Steady state II } \\
\hline & $\begin{array}{c}\text { Time* } \\
(\mathrm{s})\end{array}$ & $\begin{array}{c}\mathrm{X} \\
(\mathrm{mol} \%)\end{array}$ & $\mathrm{H}_{2} / \mathrm{CO}$ & $\begin{array}{c}\text { Time } \\
(\mathrm{s})\end{array}$ & $\begin{array}{c}\mathrm{X} \\
(\mathrm{mol} \%)\end{array}$ & $\begin{array}{c}\mathrm{H}_{2} / \mathrm{CO} \\
\text { Time }^{\&} \\
(\mathrm{~s})\end{array}$ & $\begin{array}{c}\mathrm{X} \\
(\mathrm{mol} \%)\end{array}$ & $\mathrm{H}_{2} / \mathrm{CO}$ \\
\hline $\mathrm{Cu}$, air & 350 & 12 & 2.0 & 420 & 20.5 & $2.5 \pi$ & 800 & 11 & 3.2 \\
\hline $\mathrm{Cu}, \mathrm{O}_{2}$ & 250 & 15 & 2.0 & 350 & 23.2 & $2.5 \pi$ & 800 & 11 & 5.0 \\
\hline $\mathrm{Co}$, air & 1100 & 11 & 2.0 & 1300 & 31.4 & $3.3 \pi$ & 4500 & 10.5 & 8.8 \\
\hline $\mathrm{Co}, \mathrm{O}_{2}$ & 4200 & 10 & 2.0 & 4600 & 28.1 & $3.3 \pi$ & 8000 & 11 & 8.0 \\
\hline $\mathrm{Ta}$, air & 150 & 28 & 2.2 & 250 & 58 & 2.3 & 2000 & 10.2 & 20 \\
\hline $\mathrm{Ta}, \mathrm{O}_{2}$ & 150 & 22 & 2.2 & 260 & 57.5 & 3.5 & 2500 & 10.2 & 30 \\
\hline
\end{tabular}

* onset; ${ }^{\circledR}$ minimum time. 


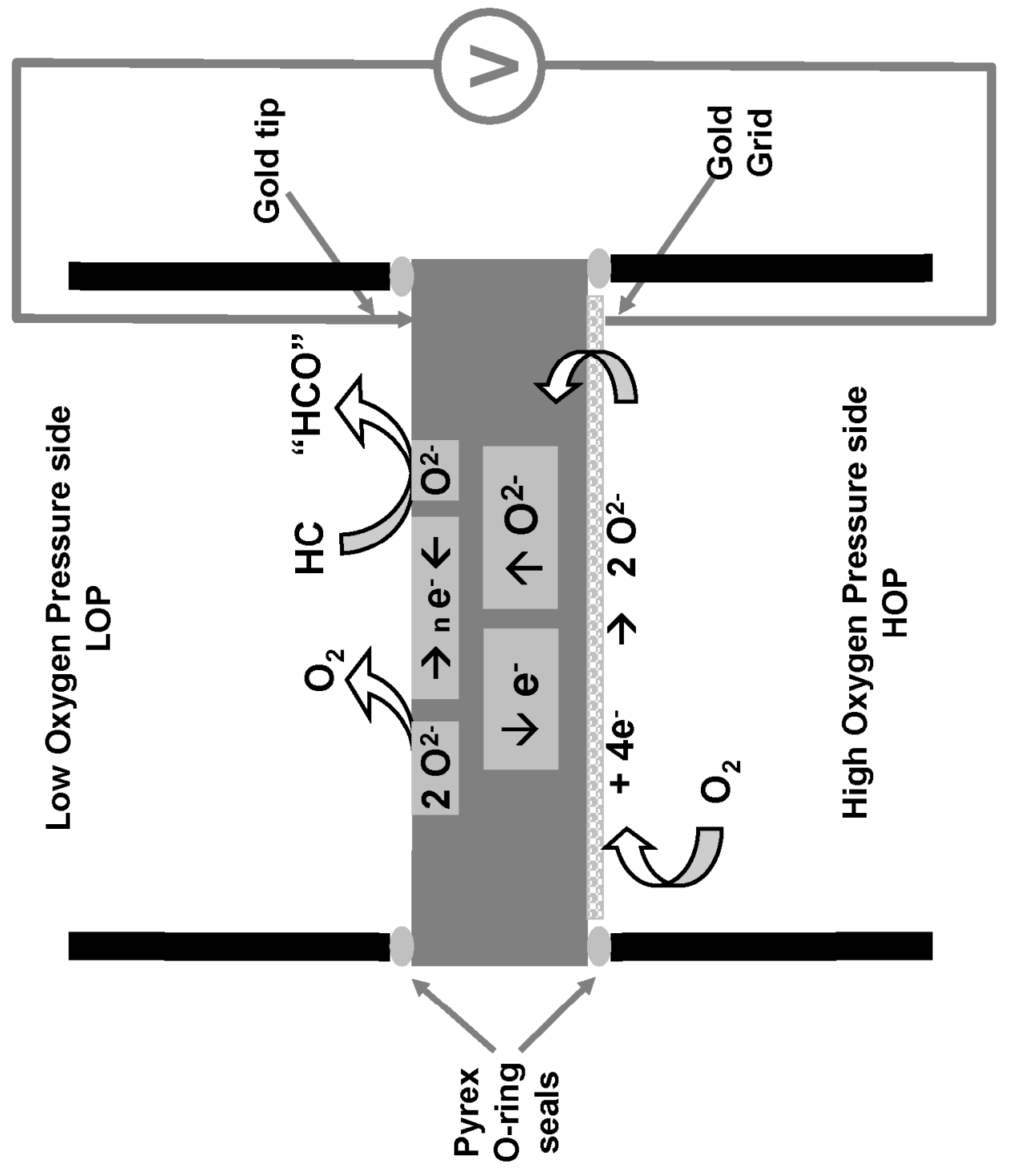




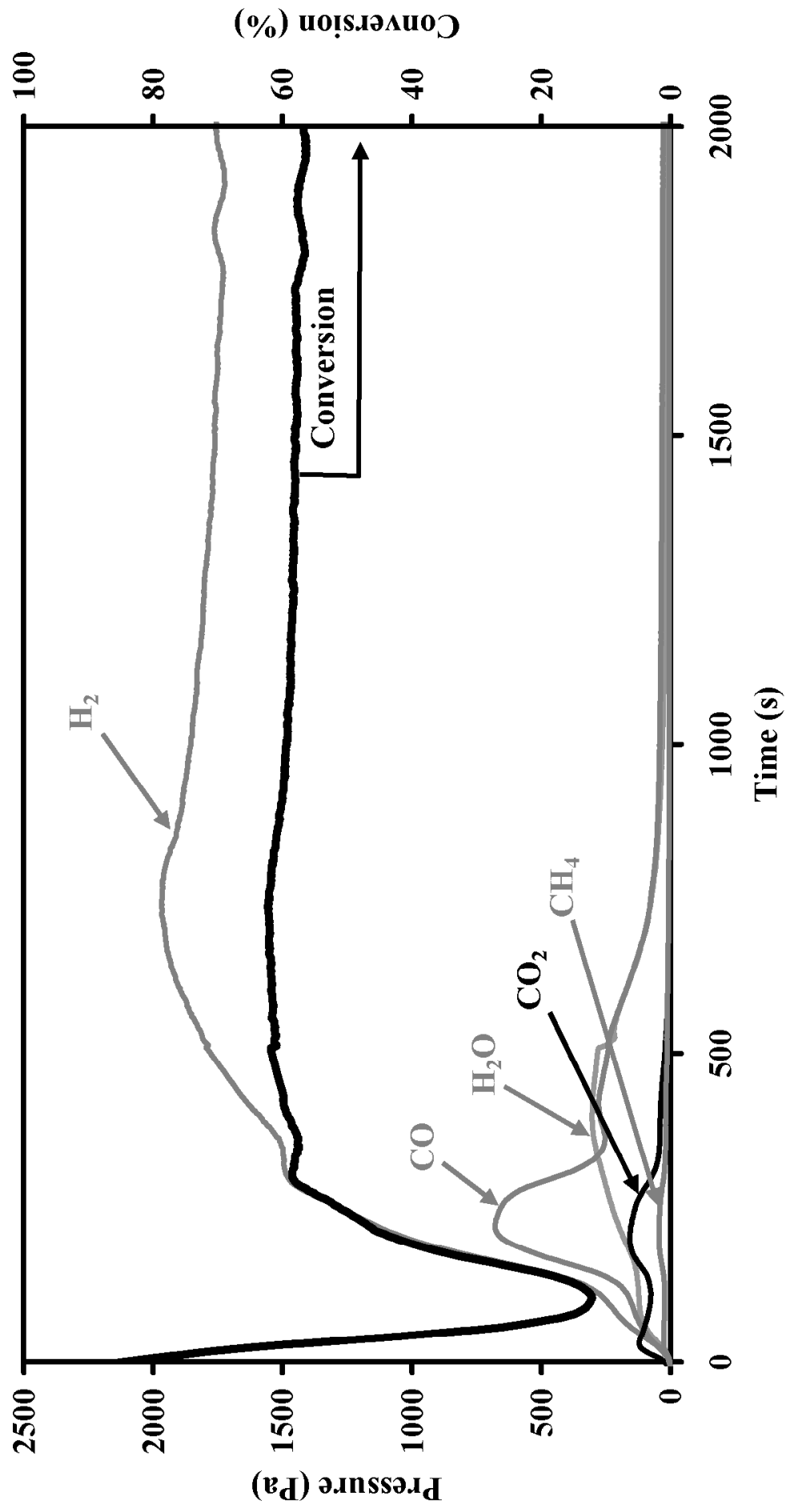




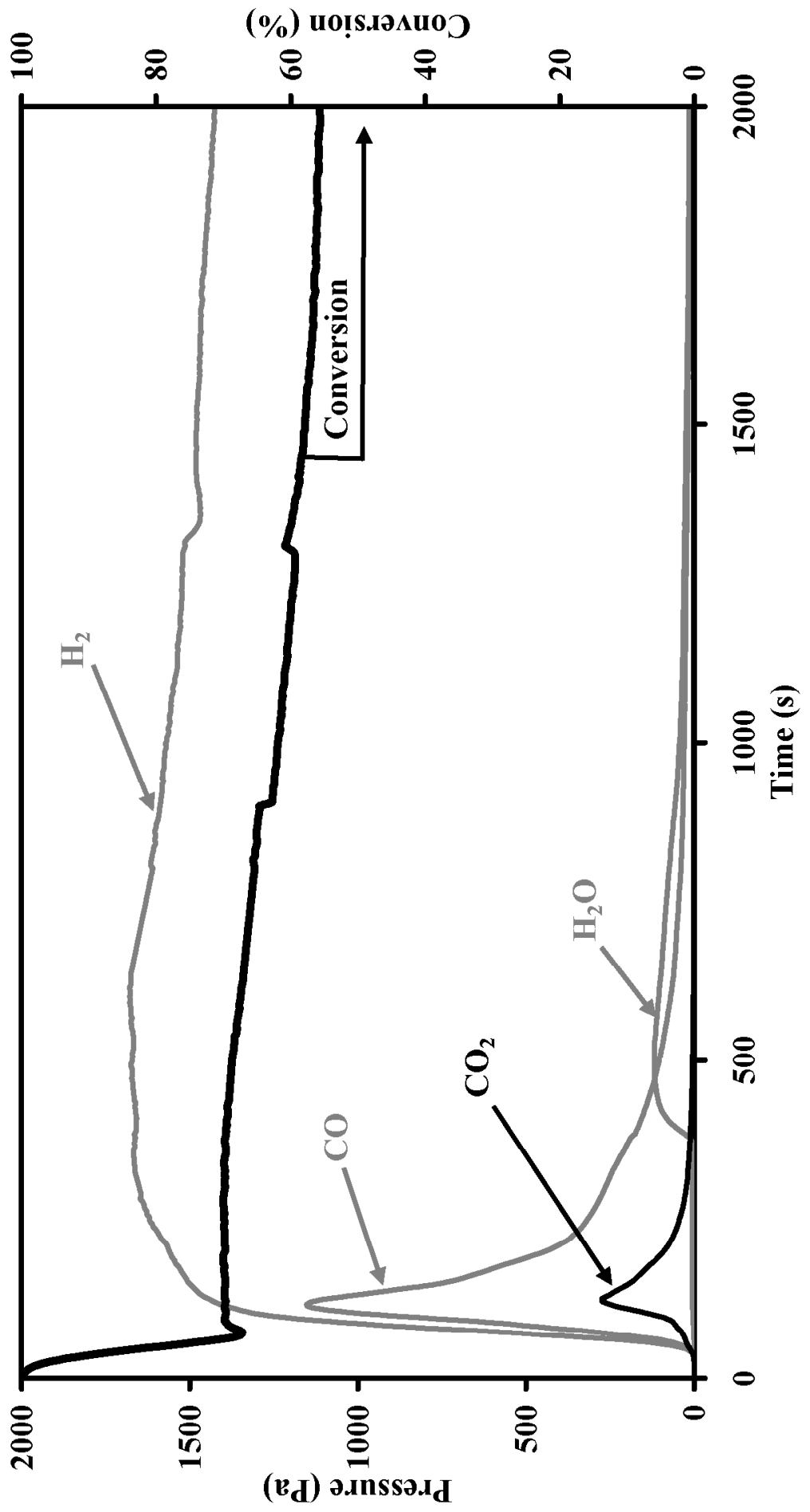




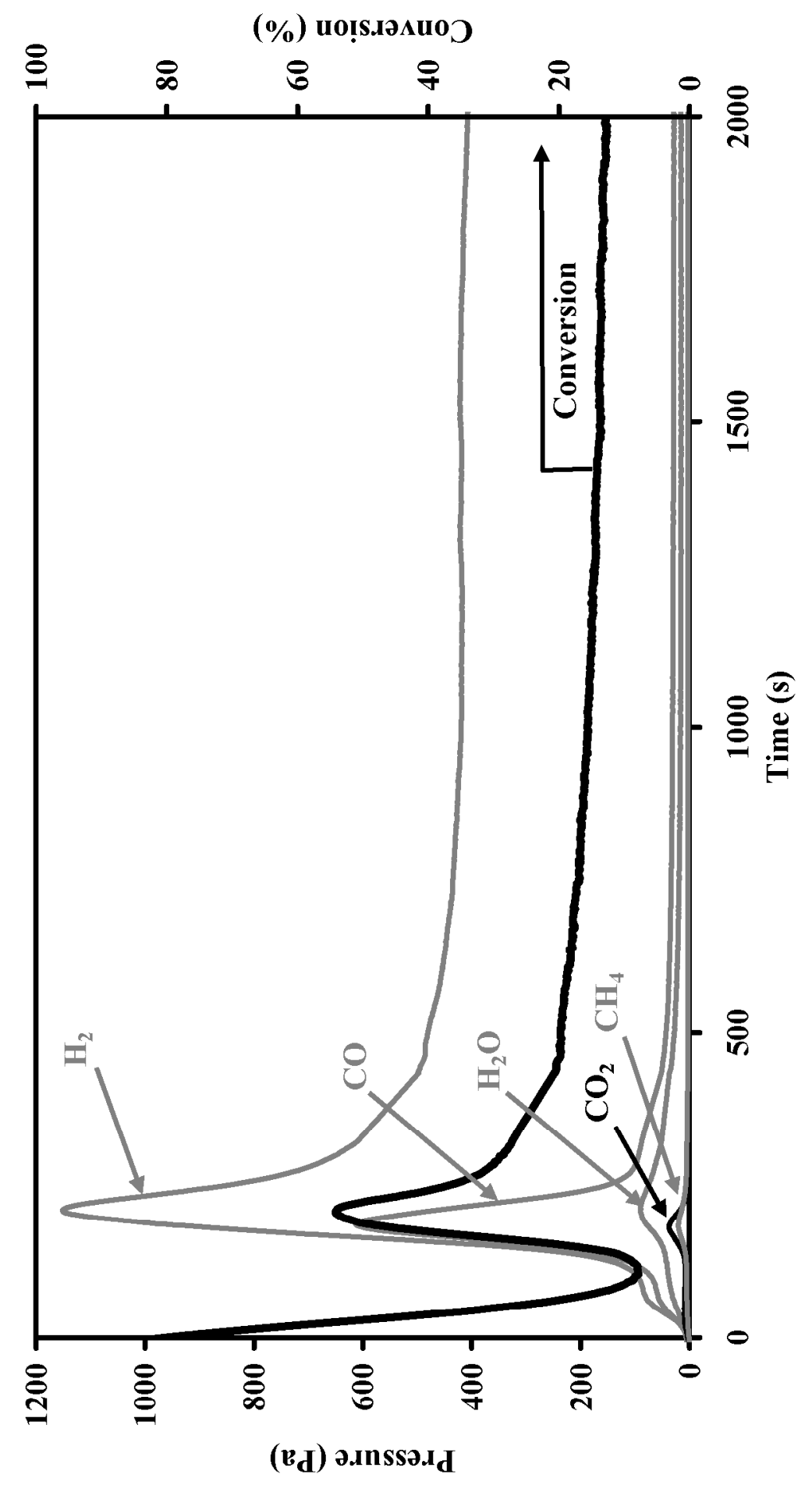




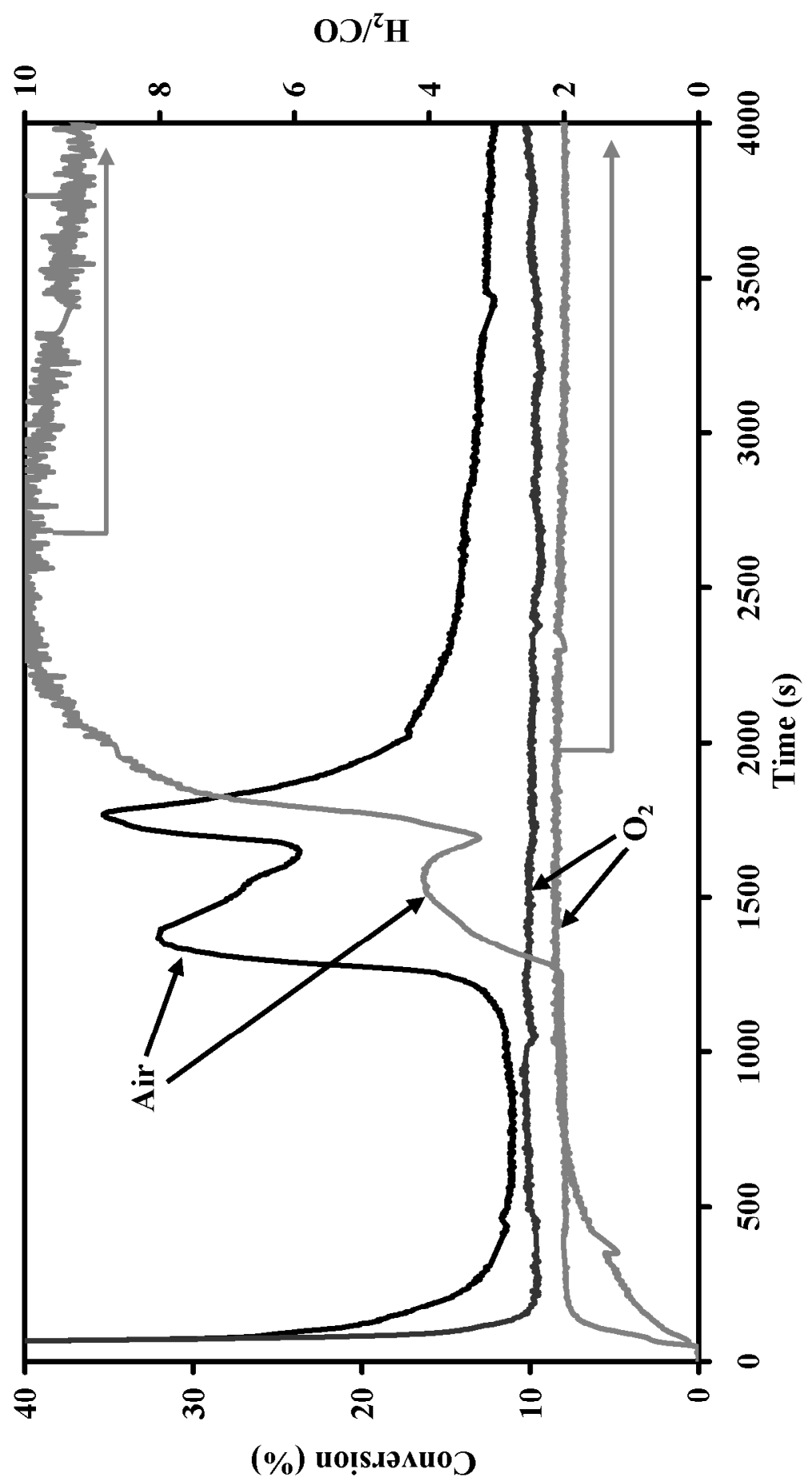




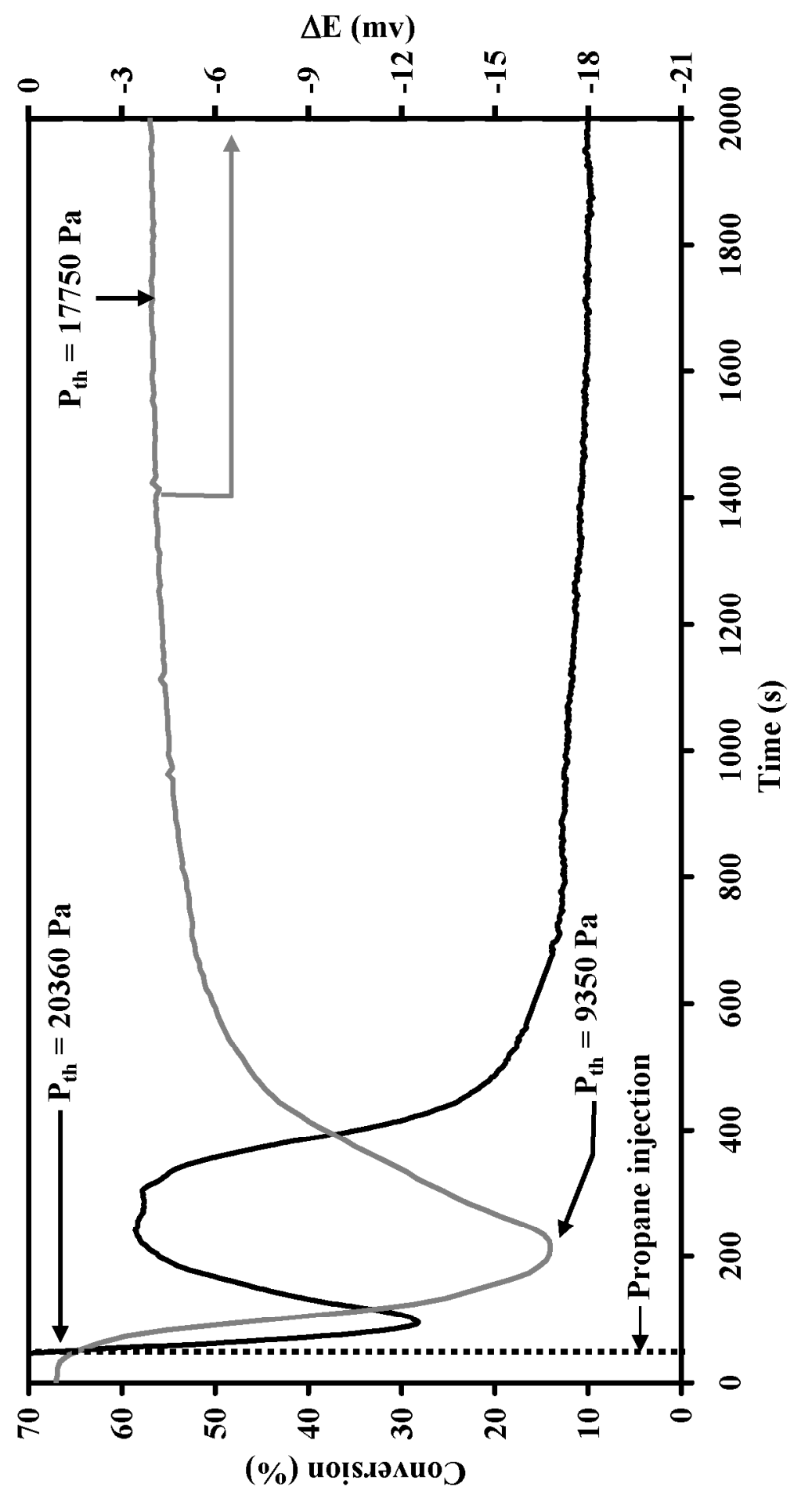




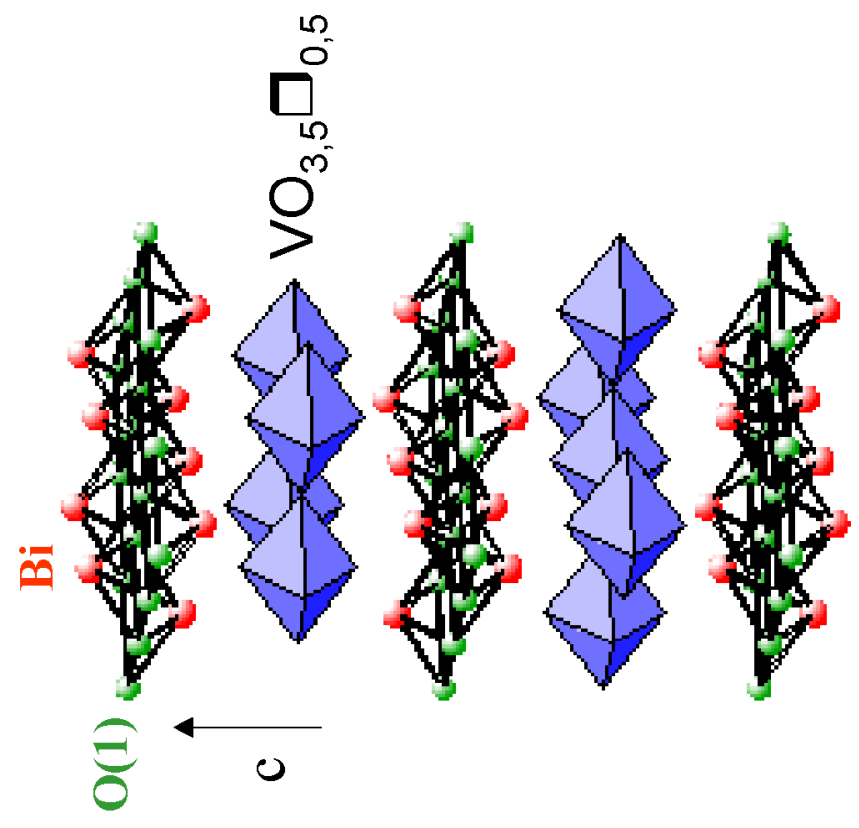



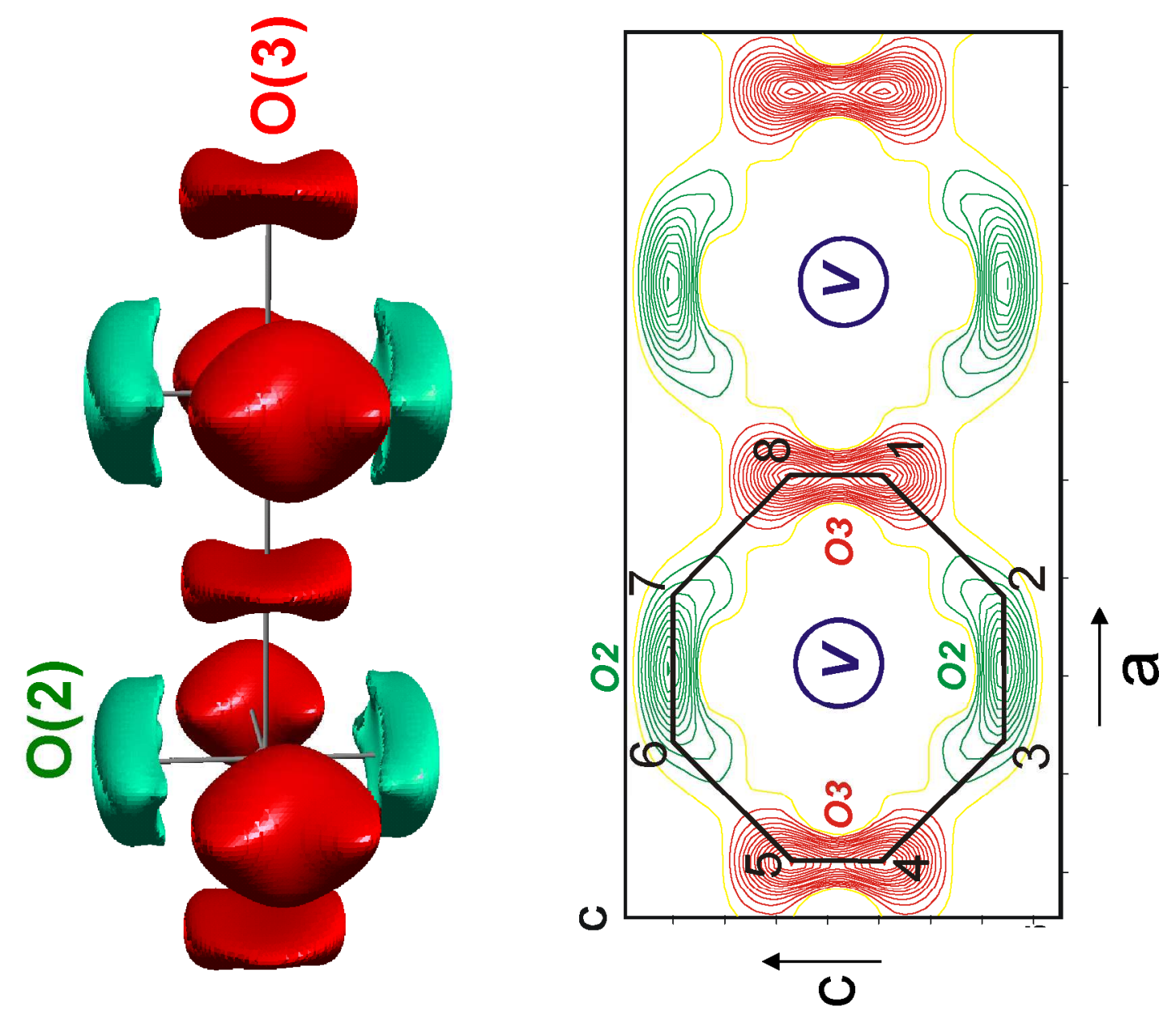

ชั

อ 


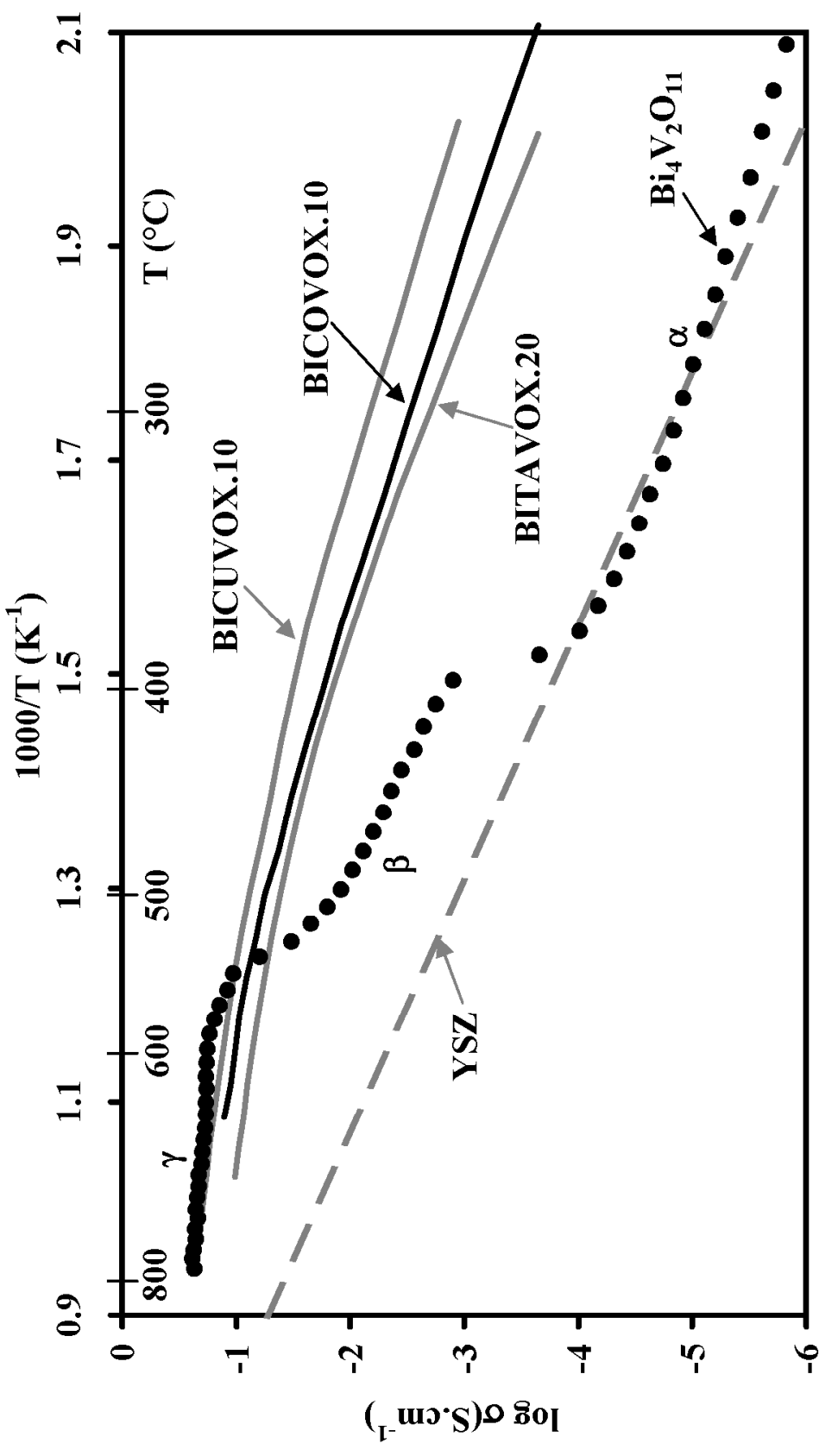

